\title{
A Study on Organisational Commitment with Special Reference to Neyveli Lignite Corporation
}

\author{
C. Murali Kumaran, Dr. M. Sivasubramanian \\ Research Scholar, Assistant Professor cum Liaison Officer, Business Administration Wing, Directorate of \\ Distance Education, Annamalai University. \\ Research Guide, Professor Business Administration, Business Administration Wing, Directorate of Distance \\ Education, Annamalai University.
}

\begin{abstract}
In organizational behaviour and industrial and organizational psychology, organizational commitment is the individual's psychological attachment to the organization. The basis behind many of these studies was to find ways to improve how workers feel about their jobs so that these workers would become more committed to their organizations. Organizational commitment predicts work variables such as turnover, organizational citizenship behavior, and job performance. This present study access the level of organisational commitment and the factors influencing the organisational commitment. . It is also found that a moderate level of organisational commitment was found among the respondents. It is also concluded that training and development, work-life policies and empowerment practice influences the level of organisational commitment of the respondents.
\end{abstract}

Key words: Organisational commitment, training and development, work-life policies, empowerment practices

\section{Introduction}

In organizational behaviour and industrial and organizational psychology, organizational commitment is the individual's psychological attachment to the organization. The basis behind many of these studies was to find ways to improve how workers feel about their jobs so that these workers would become more committed to their organizations. Organizational commitment predicts work variables such as turnover, organizational citizenship behavior, and job performance. Some of the factors such as role stress, empowerment, job insecurity and employability, and distribution of leadership have been shown to be connected to a worker's sense of organizational commitment.

Organisational commitment is employee's commitment to the organisation. It has two facets; one the organisation's perspective and the other employee's. Commitments develop naturally.

Commitment can be in form of the nature of relationship between an employee and the organisation or relationship to a variety of entities. Commitment can be observed as an attitude or mindset (attitudinal commitment) where the commitment arises due to convergence of goals and values and develops prospectively. Commitment can be behavioral where it develops post membership in retrospect which facilitates rationalization of continuance in an organisation or a course of action.

Organisational commitment has been defined as "a psychological state that characterizes an employee's relationship with an organisation and has implications for the decision to continue membership of the organisation" (Meyer and Allen 1991).

There are three components of organisational commitment. Affective commitment refers to employee's identification, or strong emotional attachment and involvement in the organisation. Continuance commitment refers to an awareness of the costs associated with leaving the organisation. Normative commitment reflects an obligation to continue with the organisation.

Although, initially literature suggested the presence of a second classification of commitment in form of compliance, identification and internalization (o'rielly, chatman and Caldwell 1991); it is now considered that identification and internalization are mechanisms through which commitment develops (Meyer and Allen 1997). Thus commitment is a multidimensional construct. (https://www.google.co.in/ Organisational\%2520 Commitment \%2520thesis.doc).

Commitment has usually been studied as an individual level variable. Studies have also looked at commitment as an organisation/ group level variable. Ostroff (1992) showed that aggregation of commitment scores of individuals is meaningful when there has been consensus among members of the group. The correlation between commitment at group level and performance has shown to be stronger than what was seen at individual level. This present study attempts to access the level of organisational commitment and the factors influencing the organisational commitment. 


\section{Review of Literature}

The findings Alexander Newman shows that there was no evidence was found of any impact of motivation to learn and perceived benefits of training on organizational commitment. This may be explained by three factors; the involuntary nature of employee training, the limited career development opportunities on offer to local employees of multinational enterprises and the difficulty employees face in applying learnt skills given cultural differences. The implications for research and practice are discussed.

Amstrong, 1999 asserts that "it is difficult to deny that it is desirable for management to have defined strategic goals and values. And it is equally desirable from management point of view for employees to behave in a way that support those strategies and values." Creating commitment includes communication, education, training programmes, and initiatives to increase involvement and ownership and the development of performance and reward management systems.

Dornstein and Matalon (1998) describe eight variables that are relevant to organizational commitment. These are interesting work, coworker's attitudes towards the organization, organizational dependency, age, education, employment alternatives, attitude of family and friends. The variables explain $65 \%$ of the variance in organizational commitment.

Guest (1991) concludes that high organizational commitment is associated with lower turnover and absence, but there is no clear link to performance. It is probably wise not to expect too much from commitment as a means of making a direct and immediate impact on performance. It is not the same as motivation. Commitment is a broader concept and tends to withstand transitory aspects of an employee's job. It is possible to be dissatisfied with a particular feature of a job while retaining a reasonably high level of commitment.

Mahnaz Kargar (2012). The obtained results indicated that age increase or decrease did not lead to increase or decrease in organizational commitment. There was no significant relationship between job background and organizational commitment. Females and males behaved in terms of organizational commitment equally. There was no significant relationship between faculties and employees in terms of organizational commitment.

Mowday, Porter, and Steer (1982) see commitment as attachment and loyalty. These authors describe three components of commitment:

- an identification with the goals and values of the organization;

- a desire to belong to the organization; and

- a willingness to display effort on behalf of the organization.

Northcraft and Neale (1996), commitment is an attitude reflecting an employee's loyalty to the organization, and an ongoing process through which organization members express their concern for the organization and its continued success and well being.

Organizational commitment is determined by a number of factor, including personal factors (e.g., age, tenure in the organization, disposition, internal or external control attributions); organizational factors (job design and the leadership style of one's supervisor); non-organizational factors (availability of alternatives). All these things affect subsequent commitment (Nortcraft and Neale, 1996)

Salancik (1977) conceives commitment as a state of being in which an individual becomes bound by his actions and it is these actions that sustain his activities and involvement. From this definition, it can be inferred that three features of behaviour are important in binding individuals to act: visibility of acts, the extent to which the outcomes are irrevocable; and the

degree to which the person undertakes the action voluntarily.

\section{Objectives}

1. To study the demographic profile of the respondents.

2. To access the level of opinion on training and development, work-life policies and empowerment practices of the respondents.

3. To access the level of organisational commitment of the respondents.

4. To study the factors influencing organisational commitment.

\section{Methodology}

Descriptive research design was adopted for the present study. The universe of the present study is the employees of Neyveli Lignite Corporation Limited, Neyveli. The researcher adopted simple random sampling for selecting the 150 sample for the study. The researcher used interview schedule as a tool for collecting data. 
The interview schedule consisted of five sections. 1. Personal details, 2. Training and development, 3. Work-life policies, 4. Empowerment practices and 5. Organisational Commitment. Data was collected from both primary and secondary sources. The data were analyzed using various statistical tools like mean, standard deviation, $\mathrm{t}-$ test, coefficient of correlation and ANOVA.

\section{Demographic Profile}

\begin{tabular}{|c|c|c|c|c|}
\hline S.no & Variable & Particulars & Frequency & Percentage \\
\hline \multirow[t]{3}{*}{1.} & \multirow[t]{3}{*}{ Age } & Below 30 & 10 & 6.7 \\
\hline & & $30-40$ & 95 & 63.3 \\
\hline & & Above 40 & 45 & 30.0 \\
\hline \multirow[t]{2}{*}{2.} & \multirow[t]{2}{*}{ Gender } & Male & 111 & 74.0 \\
\hline & & Female & 39 & 26.0 \\
\hline \multirow[t]{3}{*}{3.} & \multirow[t]{3}{*}{ Marital Status } & Married & 130 & 86.7 \\
\hline & & Unmarried & 14 & 9.3 \\
\hline & & Widow & 6 & 4.0 \\
\hline \multirow[t]{3}{*}{4.} & \multirow[t]{3}{*}{ No. of Dependent } & 2 and Below & 111 & 74.0 \\
\hline & & $3-4$ & 35 & 23.3 \\
\hline & & 5 and Above & 4 & 2.7 \\
\hline \multirow[t]{5}{*}{5.} & \multirow[t]{5}{*}{ Educational Qualification } & Primary & 26 & 17.3 \\
\hline & & Secondary & 109 & 72.7 \\
\hline & & Higher Secondary & 9 & 6.0 \\
\hline & & Graduation & 6 & 4.0 \\
\hline & & Diploma & 26 & 17.3 \\
\hline \multirow[t]{3}{*}{6.} & \multirow[t]{3}{*}{ Designation } & Executive Level & 29 & 19.3 \\
\hline & & Supervisor Level & 16 & 10.7 \\
\hline & & Worker Level & 105 & 70.0 \\
\hline \multirow[t]{3}{*}{7.} & \multirow[t]{3}{*}{ Years of Experience } & Up to 5 & 33 & 22.0 \\
\hline & & $6-10$ & 54 & 36.0 \\
\hline & & $11 \&$ above & 63 & 42.0 \\
\hline \multirow[t]{5}{*}{8.} & \multirow[t]{5}{*}{ Monthly Income } & Below 10000 & 35 & 23.3 \\
\hline & & $10001-15000$ & 80 & 53.3 \\
\hline & & $15001-20000$ & 13 & 8.7 \\
\hline & & $20001-25000$ & 22 & 14.7 \\
\hline & & Above 25000 & 35 & 23.3 \\
\hline
\end{tabular}

The above table depicts the demographic profile of the respondents. It shows that $63.3 \%$ of the respondents belong to the age group between $30-40$ years and majority of the respondents ie. $74 \%$ were male and the rest were female. The marital status of the respondents shows that majority of them $(86.7 \%)$ were married and majority of them $74 \%$ had 2 dependents in their family. The table shows that $72.7 \%$ of the respondents had secondary level of education and majority of the respondents were workers. The table shows that $42 \%$ of the respondents had an experience of 11 years and above and $53.3 \%$ of them were earning a monthly income between Rs. 10001-15000.

Key Variables

\begin{tabular}{|c|c|c|c|c|}
\hline S.No & Variable & Particulars & Frequency & Percentage \\
\hline \multirow[t]{3}{*}{1.} & \multirow[t]{3}{*}{ Opinion on training and development } & Good & 23 & 15.3 \\
\hline & & Normal & 96 & 64.0 \\
\hline & & Poor & 31 & 20.7 \\
\hline \multirow[t]{3}{*}{2} & \multirow[t]{3}{*}{ Opinion on work-life policies } & Good & 20 & 13.3 \\
\hline & & Normal & 102 & 68.0 \\
\hline & & Poor & 28 & 18.7 \\
\hline \multirow[t]{3}{*}{3.} & \multirow[t]{3}{*}{ Opinion on empowerment practices } & Good & 26 & 17.3 \\
\hline & & Normal & 97 & 64.7 \\
\hline & & Poor & 27 & 18.0 \\
\hline \multirow[t]{3}{*}{4.} & \multirow[t]{3}{*}{ Level of Organisational commitment } & High & 25 & 16.7 \\
\hline & & Moderate & 106 & 70.7 \\
\hline & & Low & 19 & 12.7 \\
\hline
\end{tabular}

The above table depicts the level of opinion of the respondents on the selected variables. The table shows that $64 \%$ of the respondents had opined "normal "on the training and development activities of the organisation and only $15.3 \%$ had opined "Good" and 20.7 percent had opined "poor "on training and development. The table shows that $68 \%$ of them had opined "normal "on work-life policies and only 13.3\% opined "good "and 18.7\% opined poor "on work-life policies of the organisation. The table also shows that $64.7 \%$ of the respondents opined "normal "on empowerment practices and only 17.3 percent opined "good "and $18 \%$ opined "poor" on 
empowerment practices. The level of organisational commitment of the employees shows that, majority of them $70.7 \%$ had moderate level of organisational commitment and $16.7 \%$ of them had high level of organisational commitment and 12.7 percent of them had low level of organisational commitment.

\section{Relationship between the Key Variables}

Training /Development and Organisational Commitment

\begin{tabular}{|c|c|c|c|c|}
\hline S.no & Variables & Statistical Tool & Value & Significance \\
\hline 1. & Training /Development and Organisational Commitment & Correlation & $\mathrm{r}=0.208 \mathrm{p}<0.05$ & Significant \\
\hline
\end{tabular}

The above table shows that there is a significant relationship between opinion on training and development and level of organisational commitment of the respondents at 0.05 level. It is interpreted that better the training and development higher is the level of commitment.

Work-life Policies and Organisational Commitment

\begin{tabular}{|c|c|c|c|c|}
\hline S.no & Variables & Statistical Tool & Value & Significance \\
\hline 1. & Work-life Policies and Organisational Commitment & Correlation & r $=0.294 \mathrm{p}<0.01$ & Significant \\
\hline
\end{tabular}

The above table shows that there is a significant relationship between opinion on work-life policies and level of organisational commitment of the respondents at 0.01 level. It is interpreted that better the work-life policies higher is the level of commitment.

\section{Empowerment Practices and Organisational Commitment}

Empowerment Practices and Organisational Commitment
\begin{tabular}{|c|l|c|c|c|}
\hline S.no & \multicolumn{1}{|c|}{ Variables } & Statistical Tool & Value & Significance \\
\hline 1. & $\begin{array}{l}\text { Empowerment Practices and Organisational } \\
\text { Commitment }\end{array}$ & Correlation & $\mathrm{r}=0.452 \mathrm{p}<0.01$ & Significant \\
\hline
\end{tabular}

The above table shows that there is a significant relationship between opinion on empowerment practices and level of organisational commitment of the respondents at 0.01 level. It is interpreted that better the empowerment practices higher is the level of commitment.

\section{Conclusion}

Organizational commitment is an attitude toward employees' loyalty to organization and a consistent process in which people's cooperation with organizational decisions depicts their attention to organization and its success. As a whole, lack of commitment and low level commitment incur negative consequence for organization and each individual. Turnover, too much absence, lack of job involvement, low quality job, lack of organizational loyalty, illegal activities against the organization, vilification and cavil about organization, decreasing customer's reliability and income are instances of these consequences.

From the findings of the study it is concluded that the opinion of the respondents towards training, work-life policies and empowerment practices of the organisation was found to be normal. It is also found that a moderate level of organisational commitment was found among the respondents. It is also concluded that training and development, work-life policies and empowerment practice influences the level of organisational commitment of the respondents.

\section{Reference}

[1]. Alexander Newman. The Impact of Employee Perceptions of Training on Organisational Commitment and Turnover Intentions: A Study of Multinationals in the Chinese Service Sector https://eprints.mdx.ac.uk/4706/1/Thanacoody-Impact of employee perceptions....pdf

[2]. Armstrong, M. (1999). Human resources management practice. London: Kogan Page.

[3]. Dornstein, M., \& Matalon, Y. (1998). A comparative analysis of predictors of organizational

[4]. commitment. A study of voluntary army personnel in Isreal. Journal of Vocational Behaviour 34 (2), $192-203$

[5]. Guest, E.A. (1991). Human resource management. London: McGraw-Hill.

[6]. Mahnaz Kargar (2012). Evaluation of Organizational Commitment of Employees in University; Case Study: Islamic Azad University. Journal of Basic and Applied Scientific Research, 2(5)5017-5021, 2012

[7]. Mooday, R.T., Porter, L.W., \& Steer, R.M. (1982). Employees organization linkages. New York: Academic Press.

[8]. Northcraft, T. \& Neale, H. (1996). Organisation Behaviour. London: Prentice-Hall.

[9]. Salancik, G.R. (1977).Commitment and the control or organizational behaviour and belief. In B Staw and G. Salancik (ed), New direction in organizational behaviour. Chicago: St Clair Press, pp. 1-59. 